\title{
BRCA1 in hormonal carcinogenesis: basic and clinical research
}

\author{
E M Rosen, S Fan and C Isaacs
}

Department of Oncology, Lombardi Cancer Center, Georgetown University, 3970 Reservoir Road, NW, Washington, District of Columbia 20057, USA

(Requests for offprints should be addressed to E M Rosen; Email: emr36@georgetown.edu)

\begin{abstract}
The breast and ovarian cancer susceptibility gene-1 (BRCA1) located on chromosome 17q21 encodes a tumor suppressor gene that functions, in part, as a caretaker gene in preserving chromosomal stability. The observation that most BRCA1 mutant breast cancers are hormone receptor negative has led some to question whether hormonal factors contribute to the etiology of $B R C A 1$-mutant breast cancers. Nevertheless, the caretaker function of $B R C A 1$ is a generic one and does not explain why $B R C A 1$ mutations confer a specific risk for tumor types that are hormoneresponsive or that hormonal factors contribute to the etiology, including those of the breast, uterus, cervix, and prostate. An accumulating body of research indicates that in addition to its wellestablished roles in regulation of the DNA damage response, the BRCA1 protein interacts with steroid hormone receptors (estrogen receptor (ER- $\alpha$ ) and androgen receptor (AR)) and regulates their activity, inhibiting ER- $\alpha$ activity and stimulating AR activity. The ability of BRCA1 to regulate steroid hormone action is consistent with clinical-epidemiological research suggesting that: (i) hormonal factors contribute to breast cancer risk in BRCA1 mutation carriers; and (ii) the spectrum of risk-modifying effects of hormonal factors in BRCA1 carriers is not identical to that observed in the general population. These data suggest a model for BRCA1 carcinogenesis in which genomic instability leads to the initiation of cancerous cell clones, while loss of normal restraint on hormonal stimulation of mammary epithelial cell proliferation allows amplification of these pre-existing clones. Further research will be required to substantiate this hypothesis.
\end{abstract}

Endocrine-Related Cancer (2005) 12 533-548

\section{Introduction}

The first breast cancer susceptibility gene, $B R C A 1$, was identified and cloned in 1994 by Miki and colleagues after an intensive search (Miki et al. 1994). A year later, a second breast cancer susceptibility gene, BRCA2 was identified (Wooster et al. 1995, Tavtigian et al. 1996). Mutations of BRCA1 or BRCA2 account for most hereditary breast cancer and breast plus ovarian cancer families, although there are a sufficient number of non-BRCA1/BRCA2 breast cancer families to suggest the existence of at least one additional $B R C A$ gene. A recent study of 11847 individuals from $699 B R C A 1$ mutant breast cancer families suggests that in addition to breast and ovarian cancers, $B R C A 1$ mutation carriers have a significantly increased risk of pancreatic, endometrial, and cervical cancers and for prostatic cancers in men younger than age 65
(Thompson et al. 2002). Breast, endometrial, and prostate cancers are all known to be steroid hormone-responsive tumor types: the first two are estrogen-responsive, while the third is androgenresponsive. In addition, there is evidence supporting a role for estrogen in stimulating cell growth during the pathogenesis of cervical cancer in animal models and in humans (Elson et al. 2000, Arbeit et al. 2003, de Villiers 2003, Li et al. 2003) although the hormonal etiology of cervical cancer is not as well established as in the other tumor types. BRCA2 mutations have been linked to ovarian, pancreatic, and prostatic cancers; but unlike $B R C A 1, B R C A 2$ mutations have not been linked to cervical and endometrial cancers (Streuwing et al. 1997, Liede et al. 2004, Lubinski et al. 2004). These findings suggest that endocrine factors may contribute to BRCA1-dependent cancer development. 
$B R C A 1$ fulfills the criteria for a tumor suppressor gene (TSG), since the vast majority of cancers that develop in mutation carriers exhibit loss of the wildtype allele (Merajver et al. 1995). This consideration implies that its normal function is required to block tumor development. During the 10 years since its discovery, a variety of studies have established functional roles for BRCA1 in DNA damage signaling, several different DNA repair processes, apoptosis susceptibility, and several DNA damage-responsive cell cycle checkpoints (Venkitaraman 2002, Rosen et al. 2003). Consistent with these functional roles, cultured cells and tumors deficient for BRCAl exhibit a pattern of severe genomic instability, characterized by aneuploidy, centrosomal amplification, and chromosomal aberrations (Tirkkonen et al. 1997, Xu et al. 1999a, Weaver et al. 2002). Taken together, these data suggest that BRCAl may function as a 'caretaker' in preserving the integrity of the genome. Loss of this caretaker function may explain why $B R C A 1$ mutations predispose to the development of cancer, but it does not by itself explain the predilection to specific tumor types, particularly breast cancer and other hormonedependent tumors. In order to elucidate the reasons that BRCAl mutations confer risk for hormoneresponsive cancers, this review will cover basic science aspects of BRCA1:hormone interactions and clinicalepidemiological aspects of this topic.

\section{Basic research}

\section{The BRCA1 gene and protein}

The human BRCA1 gene occupies a region of about 100 kilobases on chromosome 17q21 and contains 24 exons, 22 of which are coding exons and two of which are non-coding (Miki et al. 1994). The BRCA1 protein does not exhibit any significant structural homology to other known proteins except for the presence of a conserved N-terminal RING finger domain (amino acid 20-64) and a C-terminal acidic domain capable of mediating transcriptional activation when linked to a suitable DNA-binding domain (Miki et al. 1994, Monteiro et al. 1996). The N-terminal RING domain of BRCA1 interacts with another RING finger protein, BARD1 (BRCA1-associated ring domain protein 1) and the BRCA1:BARD1 complex mediates a ubiquitin ligase activity that may be important for tumor suppression (Hashizume et al. 2001). The C-terminal transcriptional activation domain (TAD) of BRCA1 contains a tandem repeat of 95 amino acids called a BRCA1-associated C-terminal domain (BRCT) that is homologous to similar domains contained in various DNA repair and cell cycle checkpoint proteins (Bork et al. 1997). The BRCA1 protein contains functional nuclear import and nuclear export signals, suggesting that it may shuttle back and forth between the nucleus and cytoplasm, although it appears that most, if not all, BRCA1 functions occur within the nucleus (Thakur et al. 1997, Rodriguez \& Henderson 2000).

The BRCA1 protein is a $220-\mathrm{kDa}$ (predominantly) nuclear phosphoprotein that is expressed and phosphorylated in a cyclic fashion, with maximal expression/phosphorylation in late G1 and early to mid S-phase (Rajan et al. 1996, Thomas et al. 1997). It was originally thought that BRCA1 expression is regulated by estrogen through an estrogen response element (ERE)-like sequence in its promoter. However, it was subsequently demonstrated that the induction of BRCA1 expression by estrogen in estrogen-responsive human breast cancer cells occurs indirectly, due to entry into S-phase (Marks et al. 1997). Many, if not most of BRCA1's biologic actions are mediated through regulation of transcription. While BRCA1 is not a sequence-specific DNA binding transcription factor, it can interact with a variety of transcription factors and either stimulate or inhibit their activity (e.g. p53, STAT1, c-Myc, JunB, ATF-1, and others) (Rosen et al. 2003). BRCA1 can also interact with components of the basal transcriptional machinery (e.g. RNA helicase A, RNA polymerase II), transcriptional coregulators and chromatin-modifying proteins (e.g. p300/CBP, the retinoblastoma protein (RB1), several RB-associated proteins (RbAp46 and RbAp48), histone deacetylases (HDACs), the SWI/ SNF-related transcriptional activator BRG1, the cofactor of BRCA1 (COBRA1)), and other transcriptional regulatory proteins (Rosen et al. 2003).

\section{BRCA1 regulation of steroid hormone receptor action}

\section{Estrogen receptor (ER- $\alpha$ )}

A molecular linkage between BRCA1 and estrogen action was established by the observation that exogenous BRCA1 inhibits the transcriptional activity of the liganded ER- $\alpha$ through the ERE in cultured human breast and prostate cancer cell lines (Fan et al. 1999). Transcriptional assays revealed that BRCA1 blocked the activity of the intact ER- $\alpha$ and that of the conserved C-terminal activation domain of ER- $\alpha$ (AF-2; which is linked to the ligand-binding domain) but did not inhibit the constitutively active $\mathrm{N}$-terminal activation domain (AF-1) (Fan et al. 1999, 2002). BRCA1 also blocked the 17ß-estradiol (E2)-stimulated 
expression of two estrogen-responsive genes, pS2 and cathepsin D (Fan et al. 2001a).

Further studies suggest two mechanisms for BRCA1 repression of ER- $\alpha$ : (i) a direct interaction of the BRCA1 and ER- $\alpha$ proteins; and (ii) down-regulation of p300, a nuclear receptor coactivator (Fan et al. 1998, 2001a,b, 2002, Kawai et al. 2002). The BRCA1: ER- $\alpha$ interaction was mapped to the $\mathrm{N}$-terminus of BRCA 1 and AF-2 domain of ER- $\alpha$ and did not require the presence of E2 (Fan et al. 2001a). In contrast to wild-type BRCA1 (wtBRCA1), a series of truncated BRCA1 proteins and cancer-associated mutants failed to, or showed reduced ability to, repress ER- $\alpha$ activity, consistent with the idea that ER- $\alpha$ repression contributes to BRCA1's tumor suppressor function.

As noted above, the BRCA1 N-terminal RING domain was found to interact with the BRCA1associated RING domain protein 1 (BARD1) protein (Wu et al. 1996) through a RING: RING interaction (Brzovic et al. 2001) and the RING heterodimer possesses strong ubiquitin ligase activity (Hashizume et al. 2001). It has been proposed that this ubiquitin ligase activity is required for BRCA1 tumor suppressor function; and it has been shown that the ubiquitin ligase activity is required for the function of BRCA1 in maintaining the normal state of cellular radiation resistance (Ruffner et al. 2001). With regard to ER- $\alpha$ activity, the RING domain of BRCA1 is not required for the physical interaction of BRCA1 with ER- $\alpha$ but is required for BRCA1 repression of ER- $\alpha$ activity, since two cancer-associated full-length BRCA1 point mutants that disrupt the RING domain structure $\left({ }^{61} \mathrm{Cys} \rightarrow\right.$ Gly and ${ }^{64} \mathrm{Cys} \rightarrow$ Gly $)$ failed to inhibit ER- $\alpha$ transcriptional activity (Fan et al. 2001a). The mechanism by which these RING domain mutations abrogate the ability of BRCA1 to repress ER- $\alpha$ activity is unclear. It could be through disruption of the ubiquitin ligase activity or another function of the RING. Although there is no evidence that BRCA1 causes the degradation of ER- $\alpha$, few targets of its ubiquitin ligase have been identified; and the possibility that one of these targets could contribute to the inhibition of ER- $\alpha$ is not ruled out.

wtBRCA1 down-regulated the expression of p300 but not its functional homolog, the CREB binding protein (CBP) (Fan et al. 1998, 2002). Exogenous p300 or CBP rescued the wtBRCA1-mediated repression of ER- $\alpha$ activity and the rescue activity mapped to a conserved cysteine-histidine rich region $\left(\mathrm{CH}_{3}\right)$, that was necessary and sufficient for rescue (Fan et al. 2002). Interestingly, a direct interaction between the $\mathrm{CH}_{3}$ domain of $\mathrm{p} 300 / \mathrm{CBP}$ and the AF-2 domain of ER- $\alpha$ was documented, suggesting that BRCA1 and
p300/CBP may compete for binding to AF-2. Finally, the ability of p300 mutants missing the histone acetyltransferase (HAT) or steroid receptor coactivator-1 (SRC-1) binding domains to rescue the BRCA1 repression of ER- $\alpha$, coupled with the inability of coactivators glucocorticoid receptor interacting protein-1 (GRIP1) and p300/CBP-associated factor (PCAF) to rescue repression suggest that derepression and coactivation of ER- $\alpha$ are distinct actions with different structural requirements.

A more detailed study of the BRCA1:ER- $\alpha$ interaction revealed two potential contact sites for BRCA1 on ER- $\alpha$ (the major site within amino acids 338-379 and a minor site within amino acids 420-595) and two contact sites for ER- $\alpha$ on BRCA1 (amino acids $67-100$ and 101-134) (Ma et al. 2005). BRCA1 contains a conserved helical motif (amino acids 86-95) resembling a previously identified nuclear corepressor motif $(\operatorname{Lxx}(\mathrm{I} /$ $\mathrm{H}) \operatorname{Ixxx}(\mathrm{I} / \mathrm{L})$, where $\mathrm{x}=$ any amino acid), mutation of which disrupted the ability of BRCA1 to bind and repress ER- $\alpha$ (Ma et al. 2005). Based on these studies, a partial BRCA1: ER- $\alpha$ three-dimensional structure was proposed (Fig. 1). In this computer-generated model, BRCA1 heterodimerizes with ER- $\alpha$ via the anti-parallel $\alpha$-helix domain, mainly using the third helix (amino acids 80-96) of BRCA1. The ER- $\alpha$ side of the interacting surface is an $\alpha$-helix of ER- $\alpha$ (amino acids $338-379$ ), which is at the opposite side of the ER- $\alpha$ homodimerization interface. Interestingly, two tumorassociated BRCA1 mutations at the interacting surface (L63F and I89T) were found to impair the ability of BRCA1 to repress ER- $\alpha$ activity (Ma et al. 2005).

Zheng and colleagues (2001) demonstrated constitutive activation of exogenous ER- $\alpha$ in the Brca1-null mouse embryo fibroblasts (MEFs), suggesting that the endogenous BRCA1 protein may mediate the ligandindependent repression of ER- $\alpha$. Consistent with such a role for BRCA1, the same investigators also showed that BRCA1 was present at the ERE site on the promoter of the estrogen-responsive gene cathepsin $\mathrm{D}$ in MCF-7 human breast cancer cells before but not after stimulation with E2. Consistent with these findings, knockdown of endogenous BRCA1 by RNA interference conferred ER- $\alpha$ activation in MCF-7 cells in the absence of E2 (Jones et al. 2005). Furthermore, BRCA1 knockdown enhanced the degree of E2-stimulated ER- $\alpha$ activity, with a higher-fold stimulation of ER- $\alpha$ activity at lower doses of E2. These findings suggest that the absence or inactivation of BRCA1 may allow ER- $\alpha$ activation under physiologic conditions of low levels or no E2.

A second estrogen receptor, ER- $\beta$, is similar in structure to ER- $\alpha$, but exhibits a different tissue 

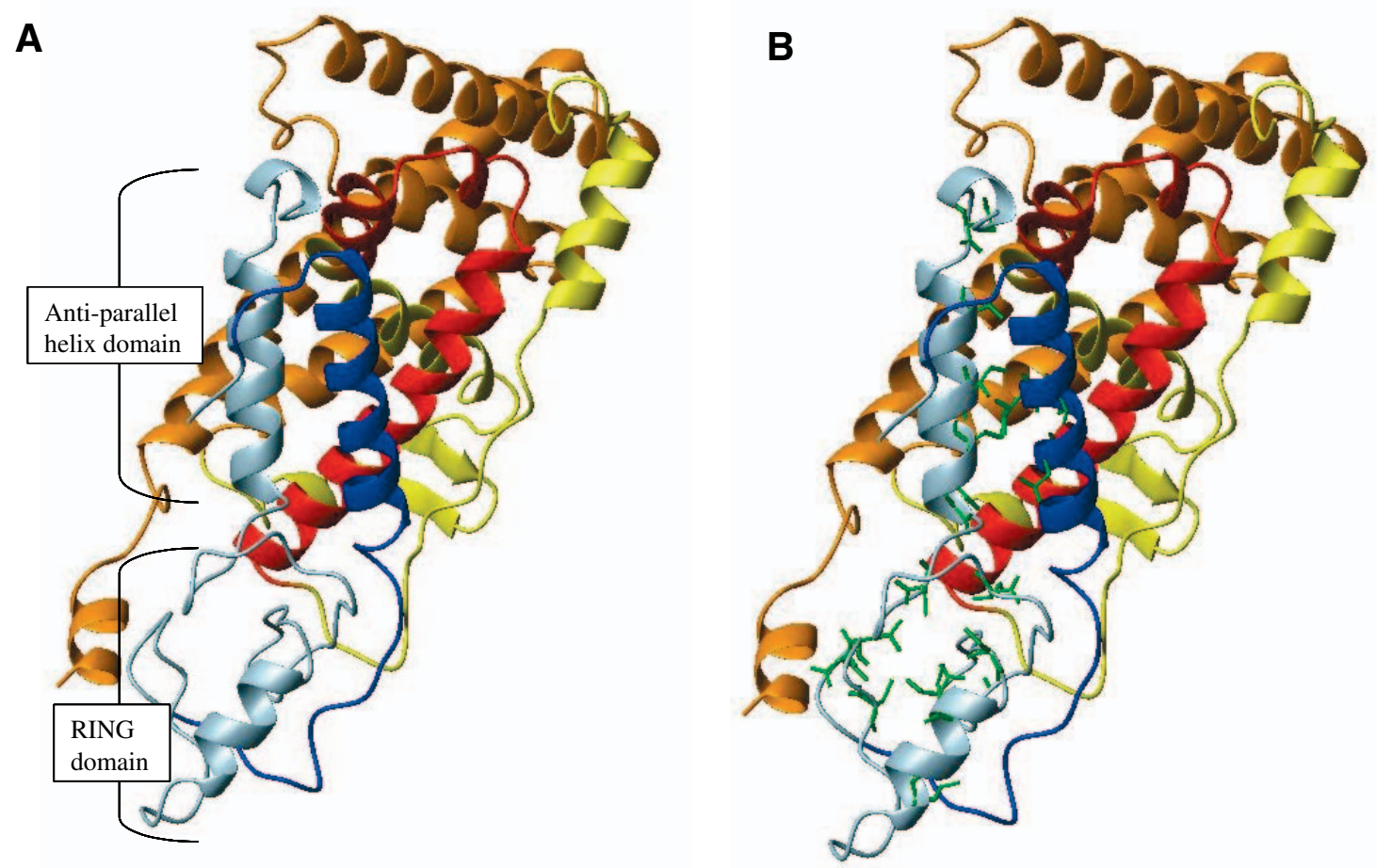

Figure 1 A model structure of the BRCA1 and ER-a complex. The interacting portions of ER- $\alpha$ and BRCA1 were docked using the Global Range Molecular Matching (GRAMM) computer program. The color scheme is as follows: blue, BRCA1 (amino acids 67-100); light blue, BRCA1 (amino acid 1-66, 101-102); green wire, tumor mutations in BRCA1; red, ER- $\alpha$ (amino acids 338-379); orange, ER- $\alpha$ (amino acids 420-595); and yellow, ER- $\alpha$ (all the rest). The BRCA1: ER- $\alpha$ complex is shown without A or with B tumor mutation sites found in breast and ovarian cancer patients (indicated by green wire).

distribution and both similar and distinct functional properties relative to ligand selectivity, binding affinity, and transcriptional activation (Mosselman et al. 1996). Several studies suggest that ER- $\beta$ may inhibit ER- $\alpha$ activity (e.g. in the uterus) and the inhibition is due, in part, to the estrogen-inducible formation of ER- $\alpha /$ ER- $\beta$ (Pettersson et al. 2000, Weihua et al. 2000, Jisa \& Jungbauer 2003). The co-expression of ER- $\alpha$ and ER- $\beta$ not only conferred a reduced sensitivity to estrogen but also caused a decrease in the agonist activity and an increase in the antagonist activity of tamoxifen (Hall \& McDonnell 1999, Pettersson et al. 2000). Whether ER- $\beta$ contributes to the ability of BRCA1 to inhibit ER- $\alpha$ activity is unknown. However, it has been recently shown that knockdown of endogenous BRCA1 levels by RNA interference enhances the agonist activity of tamoxifen (Jones et al. 2005). The possibility of a functional interaction between BRCA1 and ER- $\beta$ warrants study.

Recent work suggests the existence of a pool of ER- $\alpha$ that is localized at the plasma membrane, G-protein coupled, and mediates signaling, in part, through cross-talk with the epidermal growth factor receptor (EGFR) or insulin-like growth factor-1 receptor (IGF1R) (Kelly \& Levin 2001). Razandi and colleagues (2004) found that in the estrogen-responsive breast cancer cell lines MCF-7 and ZR-75-1, E2 caused a rapid and sustained activation of extracellular signalrelated kinase (ERK) signaling that was substantially blocked by wild-type but not mutant BRCA1 (Razandi et al. 2004). BRCA1 blocked EGF-induced ERK activation and cell proliferation through a mechanism that involves an ERK phosphatase, mitogen-activated kinase phosphatase 1. These findings suggest that BRCA1 may inhibit E2-stimulated cell proliferation, in part, by inhibiting cross talk with growth factor receptors.

\section{Androgen receptor (AR)}

Androgen receptor signaling plays a major role in human prostate carcinogenesis (Henderson \& Feigelson 2000). In several studies, BRCA1 was found to interact directly with AR and stimulate its activity 
(Park et al. 2000, Yeh et al. 2000). BRCA1 upregulated the AR-mediated expression of the G1 cell cycle inhibitor $\mathrm{p} 21^{\mathrm{WAF} 1}$ and enhanced dihydrotestosterone (DHT)-induced cell death in human prostate cancer cells (Yeh et al. 2000). BRCA1 was also found to interact directly with both AR and the coactivator GRIP1 and to stimulate AR activity via the activation factor (AF-1) domain of AR (Park et al. 2000). The ability of BRCA1 to stimulate AR activity was enhanced by several coactivators, including CBP, ARA55, ARA70 and GRIP1.

AR mutations have been linked to the development of male breast cancer, and androgens can inhibit the proliferation of breast cancer cells and block E2-stimulated proliferation, suggesting a potential role for the AR in mammary carcinogenesis (Ando et al. 2002). The AR exhibits genetic polymorphism in the number of polyglutamine (CAG) repeats in its AF-1 domain, with the repeat length inversely correlated with p160 coactivator binding and AR activity. Some studies suggest an association between a long CAG repeat length and an early age of breast cancer onset in BRCA1 mutation carriers, while other do not show such a correlation (Ferro et al. 2002).

\section{Regulation of BRCA1 expression by agents that regulate steroid hormone receptor action}

Indole-3-carbinol (I3C) is a micronutrient found in cruciferous vegetables (e.g. cabbage) with cancer preventive activity, particularly for E2-dependent cancers (breast, cervical and endometrial; Shertzer \& Senft 2000). Diets rich in these vegetables have been linked to a decreased risk of breast cancer; and dietary supplementation with cruciferous vegetables or with I3C itself blocks the formation of E2-dependent tumors in animals. I3C-mediated protection against mammary carcinogenesis is thought to be due, in part, to stimulation of metabolism of estrone through the 2-hydroxylation pathway, which yields inactive products, at the expense of 16-hydroxylation, which yields potentially carcinogenic metabolites (Bradlow et al. 1991). Recently, it was found that I3C and its major active metabolite diindolylmethane (DIM) up-regulate BRCA1 mRNA and protein expression in breast and cervical cancer cell lines (Meng et al. 2000a,b, Carter et al. 2002). It was also found that I3C inhibits ER- $\alpha$ activity, raising the possibility that BRCA1 mediates some of its actions. Genistein, an isoflavenoid derived from soy with cancer prevention activity, can also upregulate BRCA1 expression (see below).

Moderate alcohol consumption is a risk factor for breast cancer and synergistically enhances risk in combination with estrogen replacement therapy (Holmes \& Willett 2004). The molecular basis for this increased risk is unclear. A recent study revealed that exposure of breast cancer cells to ethanol stimulates cell migration and invasion and enhances ER- $\alpha$ signaling (Fan et al. 2000). In addition to causing a modest increase in ER- $\alpha$ protein levels, ethanol caused a large dose-dependent decrease in BRCA1 levels, suggesting that BRCA1 loss may contribute to increased ER- $\alpha$ signaling.

Persistent organochlorines (POCs) are carcinogens that contaminate the food chain. Some POCs inhibit ER- $\alpha$ activity and may contribute to breast cancer risk. Polychlorinated biphenyls (PCBs) and 2,3,7,8tetrachlorodibenzo- $p$-dioxin (toxiphene) were found to down-regulate E2-stimulated BRCA1 mRNA expression in MCF-7 breast cancer cells (Rattenborg et al. 2002). The polycyclic aromatic hydrocarbon benzo(a)pyrene, a carcinogen, down-regulated BRCA1 expression in ER- $\alpha$ positive but not ER- $\alpha$ negative breast cancer cell lines (Jeffy et al. 2002). These findings suggest that BRCA1 may be a molecular target for both cancer prevention agents and carcinogens.

\section{Animal Studies}

\section{Role of BRCA1 in development and mammary carcinogenesis}

Several different studies showed that BRCA1 null mutations in mice lead to early embryonic lethality (day 6.5 to 9.5; Gowen et al. 1996, Hakem et al. 1996, Liu et al. 1996). The BRCAl null phenotype was characterized by widespread defects in cell proliferation due, in part, to p53 activation; and the phenotype was partially rescued by a p53 or p $21^{\mathrm{WAF} 1}$ deficiency (Hakem et al. 1997). Studies of the patterns of BRCA1 mRNA expression revealed that BRCA1 is highly expressed in multiple tissues, in rapidly proliferating cells undergoing differentiation, including mammary epithelial cells during puberty, pregnancy and lactation (Lane et al. 1995, Marquis et al. 1995). Consistent with these findings, BRCA1 expression was up-regulated in cultured mammary epithelial cells induced to differentiate (Rajan et al. 1996) and wtBRCA1 caused accelerated differentiation independently of its effects on cell proliferation and p53 transactivation, suggesting a role for BRCA1 in mediating differentiation (Kubista et al. 2002).

BRCA1 was expressed in the granulosa and theca cells of the mouse ovary independently of hormonal stimulation (Phillips et al. 1997). The pattern of expression of BRCA2 was generally similar to BRCA1; 
but differential expression was observed in endocrine tissues, including the testis during spermatogenesis and the breast during pregnancy (Rajan et al. 1997). In studies of the effect of a synthetic estrogen (diethylstilbestrol (DES)) on endocrine responses in Brcal heterozygous mice, mammary ductal branching was reduced in DES-treated heterozygotes, relative to wildtype mice (Bennett et al. 2000). Most heterozygous mice showed ovarian atrophy, as compared with wild-type mice which showed arrested follicular development. These findings suggest that Brcal may be haplo-insufficient for mediating some proliferative endocrine tissue responses to DES.

Chuxia Deng and his colleagues developed a mouse model featuring a mammary-targeted homozygous deletion of Brcal exon 11 (which codes for $>60 \%$ of the Brcal protein). These mice developed mammary cancers after a latent period of 12 months, which was significantly reduced in the setting of a heterozygous p53 deletion (Xu et al. 1999b). Mammary tumors from these mice recapitulated some of the features of BRCA1 mutant human breast cancers (e.g. chromosomal rearrangements, p53 mutations, and ER- $\alpha$ negativity) but not others (e.g. absence of HER2/Neu or cyclin D1 over-expression (see below)) (Brodie et al. 2001, Deng 2002).

A study of the effect of tamoxifen, a selective estrogen receptor modulator, in the same model revealed tamoxifen actually increased the incidence of mammary cancers in Brcal-deficient animals (Jones et al. 2005). Consistent with this finding, knockdown of endogenous BRCA1 enhanced the ER- $\alpha$ agonist activity of tamoxifen in cultured MCF-7 cells (Jones et al. 2005). Tamoxifen-induced mammary hyperplasias in the Brcal-deficient mice showed a loss of ER- $\alpha$ expression, suggesting that early loss of ER- $\alpha$ is a feature of the pathogenesis of these tumors. These findings suggest that hormonal factors can modify development of Brcal mutant mammary cancers in this model.

Interestingly, a prepubertal (age 1-3 weeks) exposure of female rats to $17 \beta$-estradiol or genistein (a phytoestrogen with mixed agonist/antagonist properties) decreased the subsequent risk of developing 7,12dimethylbenz[a]anthracene (DMBA)-induced mammary tumors (Cabanes et al. 2004). These exposures caused a persistent up-regulation of $B R C A 1$ expression in the mammary glands that was still observed at age 16 weeks. While genistein can activate ER- $\alpha$ by itself and inhibit estradiol-stimulated ER- $\alpha$ activity, it appears to be a more selective ligand for ER- $\beta$ than for ER- $\alpha$ since it competes more effectively with estradiol for binding to ER- $\beta$ than to ER- $\alpha$ (Barkhem et al. 1998, Kuiper et al. 1998, Pike et al. 1999). Whether the ability of genistein to up-regulate Brcal expression is dependent upon ER- $\beta$ remains to be determined. As noted earlier, $B R C A 1$ is normally highly expressed in proliferating mammary epithelial cells undergoing differentiation during puberty and pregnancy in mice. Taken together, these findings suggest that the expression of $B R C A 1$ during key windows of time when the mammary gland is hormonally sensitive may be critical for tumor suppression.

\section{Clinical research}

\section{Epidemiology of BRCA1 mutant cancers}

\section{Clinicopathologic characteristics of BRCA1 mutant breast cancers}

By age 70 the risk of breast cancer in $B R C A 1$ mutation carriers is estimated to be between 55 and $85 \%$, while the risk of ovarian cancer is approximately $40 \%$ (Easton et al. 1995, Streuwing et al. 1997, Warner et al. 1999, Antoniou et al. 2003). These cancers typically occur at a younger age than is seen in the general population, with studies demonstrating that approximately one third to one half of mutation carriers will be diagnosed with breast cancer by age 50 (Easton et al. 1995, Antoniou et al. 2003). The breast cancers diagnosed in BRCAl carriers differ histopathologically from tumors that occur in women with sporadic disease. These tumors are usually hormone receptor negative, with different studies indicating that only 10 to $36 \%$ of tumors in these patients are estrogen receptor positive (Verhoog et al. 1998, Lakhani et al. 2002, Robson et al. 2004). The ER- $\alpha$ negativity of these tumors may be due, in part, to hypermethylation of the ER- $\alpha$ gene (Archey et al. 2002). Interestingly, however, progesterone receptor (PR) expression was significantly higher in benign mammary epithelial cells adjacent to a $B R C A 1$ mutant breast cancer than a sporadic cancer (King et al. 2004). In addition, BRCAl mutant tumors are more frequently high grade (Breast Cancer Linkage Consortium 1997), have higher mitotic counts (Marcus et al. 1996, Breast Cancer Linkage Consortium 1997, Lakhani et al. 1998), and have medullary or atypical medullary features (Eisinger et al. 1998).

On molecular analysis, BRCA1-associated breast cancers show an increased incidence of p53 mutations (Armes et al. 1999, Phillips et al. 1999, Lakhani et al. 2002) but a decreased incidence of HER2/Neu amplification/over-expression (Johannsson et al. 1997, Armes et al. 1999, Phillips et al. 1999, Lakhani et al. 2002, Quenneville et al. 2002, Adem et al. 2004). 
Whereas cyclin D1 amplification and/or over-expression are relatively common in sporadic breast cancers, BRCA1 mutant cancers showed no cyclin D1 amplification and low levels of cyclin D1 expression (Osin et al. 1998, Armes et al. 1999, Vaziri et al. 2001). The c-Myc oncogene is amplified in $15-20 \%$ of sporadic breast cancers. In contrast to HER $2 / \mathrm{Neu}$ and cyclin D1, two recent studies reported an excess prevalence of c-Myc amplification in $B R C A 1$ mutant cancers relative to sporadic cancers (Adem et al. 2004, Grushko et al. 2004), although one study did not find an excess of c-Myc amplification in BRCA1 mutant cancers (Palacios et al. 2004). Unlike sporadic breast cancers, $B R C A 1$ mutant tumors showed frequent amplification of c-Myb, a proto-oncogene implicated in mediating cycle progression from $\mathrm{G} 2$ to $\mathrm{M}$ (Kauraniemi et al. 2000). In addition to ER- $\alpha$ and the progesterone receptor, BRCA1 mutant breast cancers also show reduced $\mathrm{AR}$ expression, as compared with sporadic cancers (Berns et al. 2003). DNA microarray and immunohistochemistry based studies indicate that breast cancers in BRCAl carriers exhibit a basal-like phenotype (Foulkes et al. 2003, Sorlie et al. 2003). The basal phenotype, which occurs in about $15 \%$ of breast cancers, is characterized by ER- $\alpha$ and HER2/Neu negativity, coupled to the expression of high levels of the cytokeratins normally found in basal epithelial cells.

Recent studies indicate that BRCA1 mRNA and protein are absent or significantly reduced in 30-40\% of sporadic breast cancer cases (Ozcelik et al. 1998, Taylor et al. 1998, Rio et al. 1999, Wilson et al. 1999). Decreased BRCA1 expression may be due to hypermethylation of the $B R C A 1$ promoter on $\mathrm{CpG}$ islands and/or loss of one of the BRCAl alleles (Rice et al. 1998, Esteller et al. 2000, Staff et al. 2003). It is not yet clear whether these BRCA1 under-expressing breast cancers represent a distinct phenotypic group. However, since most sporadic breast cancers are ER- $\alpha$ positive, these findings suggest a role for a BRCA1: hormone interaction in sporadic breast cancer development.

\section{Hormonal modifiers of cancer risk}

Given the differences in BRCA1 mutant breast cancers, particularly their preponderance toward hormone receptor negativity, the significance of endocrine factors in the development and prevention of these cancers has been questioned. The study of cancer risk modifiers provides important clues as to the impact of hormone related factors on the development of breast cancer in mutation carriers. In the general population, endocrine factors, such as age at menarche, age at menopause, age at the first full-term pregnancy, parity, breast feeding and the use of hormone replacement therapy impact breast cancer risk. Various studies have explored the role of some of these factors in BRCAI carriers and reveal that a number of them modify breast cancer risk.

\section{Parity and age at first full-term pregnancy}

Early age at first full-term pregnancy and increasing parity reduce the risk of breast cancer in the general population. However, data on the effect of these factors in mutation carriers have yielded different results, with some studies indicating no impact on cancer risk and other studies suggesting that late age at first full-term pregnancy confers protection against breast cancer and that increasing parity increases the risk of this disease. In a community-based study of over 5000 Ashkenazi Jewish women from Washington DC, women who did not carry founder mutations in $B R C A 1$ or $B R C A 2$ had about a $5 \%$ increase in risk of breast cancer with each 5 year increase in age at first birth (relative risk (RR) per 5 years $=1.05$; 95\% confidence interval $(\mathrm{CI})=0.96$ to 1.15$)$ whereas mutation carriers had a $35 \%$ decrease in risk with each 5 year increase in age at first birth (RR per 5 years $=0.65 ; 95 \% \mathrm{CI}=0.35$ to 1.12 ; Hartge et al. 2002). A case control study, which included 685 BRCA1 carriers and $280 B R C A 2$ carriers with breast cancer and matched carrier controls, showed no difference in age at first full-term pregnancy in those with and without breast cancer (Jernstrom et al. 2004). With respect to parity, this study revealed no difference in mean number of pregnancies between mutation carriers with and without breast cancer. An earlier study from the same group suggested that the risk of breast cancer prior to age 40 in $B R C A 1 / 2$ carriers increased with increasing number of births (Jernstrom et al. 1999). While the findings from this study are provocative, the number of participants was small and likely included some of the same women as were included in the later larger analysis that showed no association between parity and breast cancer risk (Jernstrom et al. 2004). Taken together, these studies suggest that the usual protective effect of early age at first birth and increasing parity is not observed in mutation carriers.

\section{Age at menarche}

While the impact of age at menarche in $B R C A$ mutation carriers was not specifically addressed, one case control study noted a very small but statistically 
significant difference in age at menarche in $B R C A 1 / 2$ mutation carriers with breast cancer and those unaffected by this disease (12.8 vs 12.9 years, $P=0.03$; Jernstrom et al. 2004). However, the majority of studies have found no significant differences in age at menarche amongst BRCAl carriers who developed breast cancer as compared with those who had not (Jernstrom et al. 1999, Rebbeck et al. 2001, 2002). Thus, in contradistinction to what is observed in the general population, these studies have not demonstrated that early age at menarche influences breast cancer risk in mutation carriers.

\section{Breast feeding}

Similar to observations in the general population, prolonged breast feeding has been shown to have a protective effect in $B R C A 1$ carriers. A recently published case-control study revealed that BRCAl carriers who breast fed for more than one year were significantly less likely to develop breast cancer than were $B R C A 1$ carriers who never breast fed (odds ratio $=0.55 ; 95 \% \quad \mathrm{CI}=0.38$ to $0.80, \quad P=0.001$; Jernstrom et al. 2004). To control for the close relationship between duration of breast feeding and parity, nulliparous women were excluded from the analysis and cases and controls were matched for parity. It has been reported that $B R C A l$ carriers may experience difficulties with milk production, raising the possibility that this factor, rather than the duration of breast feeding, is associated with the increased risk of breast cancer seen in BRCAl carriers who report a shorter duration of breast feeding.

\section{Oral contraceptive use and hormone replacement therapy (HRT)}

Although epidemiologic studies have yielded varying results, a meta-analysis of 54 studies suggests that the long-term use of oral contraceptives confers a small but significant increase in the risk of breast cancer in young women (Collaborative Group on Hormonal Factors in Breast Cancer 1996). Additionally, oral contraceptive use has also been associated with an increased risk of breast cancer in those with a first degree relative with this disease (Grabrick et al. 2000). In a case control study of $B R C A 1$ and $B R C A 2$ mutation carriers, $B R C A 1$ mutation carriers who used oral contraceptives for at least five years (odds ratio $=1.33 ; 95 \% \mathrm{CI}=1.11$ to 1.60$)$ or those who used oral contraceptives before age 30 (odds ratio $=1.29 ; 95 \% \mathrm{CI}=1.09$ to 1.52 ) had a modest but significant increase in breast cancer risk. In contrast, $B R C A 2$ carriers did not exhibit an increased risk associated with oral contraceptive use (Narod et al. 2002). Another report describes a significant increase in breast cancer risk for $B R C A l$ carriers in the first 15 years after last use (hazard ratios from 1.691.99) but in the same study users with more than 15 years since last use showed a reduced risk (hazard ratio $=0.69$; Heimdal et al. 2002). An earlier study with smaller patient numbers described an increased breast cancer risk among oral contraceptive users with either a $B R C A 1$ or a $B R C A 2$ mutation (Ursin et al. 1997).

In contrast to breast cancer, several studies suggest that oral contraceptive use confers a reduced risk of ovarian cancer in $B R C A 1$ mutation carriers, the extent of which increases with increasing duration of use (McGuire et al. 2004, Whittemore et al. 2004). Oral contraceptive use is also inversely correlated with ovarian cancer risk in the general population and the magnitude of risk reduction appears to be similar for $B R C A 1$ mutation carriers and non-carriers.

A meta-analysis of 51 epidemiologic studies on HRT in postmenopausal women revealed a modest but significant increase in risk of breast cancer associated with a prolonged duration of HRT ( $>5$ years) within the first 5 years since last HRT use but not thereafter (Collaborative Group on Hormonal Factors in Breast Cancer 1997). More recently, data from the Women's Health Initiative, a large randomized placebo controlled trial of estrogen plus progestin or estrogen alone indicated that using a combination of estrogen plus a progestin confers a higher risk for breast cancer than utilizing estrogen only (The Women's Health Initiative Steering Committee 2004, Writing Group for the Women's Health Initiative Investigators 2002). At present, there is insufficient data to ascertain whether HRT confers a significantly increased risk for breast cancer in BRCA1 mutation carriers (Narod 2001).

\section{Clinical Interventions}

The epidemiologic studies described above suggest that the hormonal milieu modifies the risk for breast cancer in BRCA1 mutation carriers, although the impact of specific factors on cancer risk may differ between the carriers and the general population. Studies on clinical interventions to prevent BRCA1 mutant cancers shed further light on the role of hormones in the etiology of these cancers.

\section{Prophylactic oophorectomy}

Studies on the effect of prophylactic oophorectomy have provided some of the most convincing evidence that hormone-related factors influence the risk of 
breast cancer in mutation carriers. This procedure removes the major source of two hormones with potent effects on mammary physiology and cancer development, estrogen and progesterone. In a multi-institution study, mutation carriers who had undergone prophylactic oophorectomy (cases) were matched by type of mutation (BRCA1 vs BRCA2), age, and institution to mutation carriers who had not undergone prophylactic oophorectomy (controls) (Rebbeck et al. 2002). None of these subjects had undergone prophylactic mastectomy. With a median follow-up of about 11 years, 21 of 99 cases $(21 \%)$ and 60 of 142 controls $(42 \%)$ had been diagnosed with breast cancer (hazard ratio $=0.47$; $95 \% \mathrm{CI}=0.29$ to 0.77 ). Similarly, in a prospective study of 170 newly identified $B R C A 1$ or $B R C A 2$ mutation carriers, breast cancer was diagnosed in 3 of the 69 women who chose to undergo bilateral salpingooophorectomy and no prophylactic mastectomy (4\%) as compared with 8 of the 62 women who underwent neither prophylactic oophorectomy nor mastectomy $(13 \%)$ (hazard ratio $=0.32 ; 95 \% \mathrm{CI}=0.08$ to 1.20$)$ (Kauff et al. 2002). While neither of these studies specifically addressed the impact of such an intervention in $B R C A 1$ as opposed to $B R C A 2$ carriers, the majority of women in both of these studies harbored $B R C A 1$ mutations $(83 \%$ and $61 \%$, respectively).

Additionally, the impact of prophylactic oophorectomy on the subsequent risk of contralateral breast cancer has been examined in carriers with breast cancer. A recent prospective study of 491 BRCA1/2 carriers with stage I or II breast cancer, demonstrated a 10 year risk of contralateral disease of $29.5 \%$ (Metcalfe et al. 2004). Amongst the 336 carriers in whom the contralateral breast was intact, prophylactic oophorectomy was associated with a $59 \%$ reduction in risk of contralateral breast cancer (hazard ratio $=0.41$; $95 \% \mathrm{CI}=0.18$ to 0.90 ). The benefit of this procedure was greatest for those who underwent prophylactic oophorectomy at less than 50 years of age (hazard ratio $=0.24 ; 95 \% \mathrm{CI}=0.07$ to 0.77 ) as compared with those who were 50 or greater (hazard ratio $=0.91$; $95 \% \mathrm{CI}=0.26$ to 3.21 ). In multivariate analyses restricted to the $224 B R C A 1$ carriers, oophorectomy was demonstrated to reduce the risk of contralateral disease (hazard ratio $=0.33 ; 95 \% \mathrm{CI}=0.13$ to 0.84 ). These data support the idea that hormonal factors play a role in the development of BRCA1 mutant breast cancers.

\section{Tamoxifen}

The National Surgical Adjuvant Breast and Bowel Project Breast Cancer Prevention Trial (NSABP-P1) examined the role of tamoxifen in reducing the risk of breast cancer in healthy women at increased risk for this disease due to a variety of predisposing factors, including family history, age, and certain high risk conditions such as lobular carcinoma in situ or atypical hyperplasia (Fisher et al. 1998). Among the whole study population in this randomized placebo-controlled trial, tamoxifen reduced the risk of invasive breast cancer by about half. Whereas tamoxifen reduced the risk of developing estrogen receptor positive tumors by $69 \%$, no significant impact on the occurrence of estrogen receptor negative disease was appreciated. Given that BRCAl carriers tend to develop hormone receptor negative breast cancers, significant debate exists as to the role of tamoxifen as a chemopreventive agent in these women.

In order to further address the potential effect of tamoxifen as a risk-reducing agent in unaffected women with hereditary breast cancer, genetic analysis was performed on 288 of the NSABP-P1 participants who developed breast cancer (King et al. 2001). Only 19 of these 288 women $(6.6 \%)$ were found to carry disease-conferring mutations. These 19 women included 8 women with $B R C A 1$ mutations and 11 with $B R C A 2$ mutations. Among $B R C A 2$ carriers, tamoxifen was associated with a decrease in risk of breast cancer (risk ratio $=0.32 ; 95 \% \mathrm{CI}=0.06$ to 1.56); whereas no reduction in risk was observed in the $B R C A 1$ carriers (risk ratio $=1.67 ; 95 \%$ CI 0.32 to 10.7). While these results suggest no benefit of tamoxifen in BRCAl carriers, the very small number of mutation carriers studied and the attendant lack of statistical significance require that these data be interpreted with caution.

In contrast to the observations from the NSABP-P1 trial, studies of mutation carriers with breast cancer suggest that tamoxifen reduces the risk of contralateral disease. In a case-control study, 209 BRCA1/2 carriers with bilateral breast cancer were compared with 384 $B R C A 1 / 2$ carriers with unilateral disease (Narod et al. 2000). Tamoxifen use was reported in $21.1 \%$ of the women with unilateral breast cancer and by $10.5 \%$ of those with bilateral disease. On multivariate analysis, the use of tamoxifen reduced the risk of contralateral breast cancer in BRCA1 carriers (odds ratio $=0.38$; $95 \% \mathrm{CI}=0.19$ to 0.74 ) and $B R C A 2$ carriers (odds ratio $=0.63,95 \% \mathrm{CI}=0.20$ to 1.50 ). In a more recent prospective study from the same group, there was a trend toward a reduced risk of contralateral breast cancer in BRCAl carriers receiving tamoxifen, however, this did not reach statistical significance (hazard ratio $=0.59 ; 95 \% \mathrm{CI}=0.26$ to 1.33 ; Metcalfe et al. 2004). Of note, neither of these two studies included 
Table 1 Effect of hormonal factors on breast cancer risk in BRCA1 mutation carriers

\begin{tabular}{lcc}
\hline Factor & $\begin{array}{c}\text { General } \\
\text { population }\end{array}$ & $\begin{array}{c}\text { BRCA1 } \\
\text { carriers }\end{array}$ \\
\hline Early age at menarche & $\uparrow$ & - \\
Increasing parity & $\downarrow$ & $-/ \uparrow$ \\
Young age at first & $\downarrow$ & $-/ \uparrow$ \\
term pregnancy & $\downarrow$ & $\downarrow$ \\
Breast feeding & $\uparrow^{*}$ & $\uparrow$ \\
Oral contraceptive use & $\uparrow^{*}$ & Insufficient data \\
Hormone replacement & & $\downarrow$ \\
therapy & $\downarrow$ & $-/ \downarrow$ \\
Oophorectomy & $\downarrow$ & \\
Tamoxifen & $\downarrow$ & \\
\hline
\end{tabular}

- no effect; $\uparrow$ increased risk; $\downarrow$ decreased risk; * see text.

data on the hormone receptor status of the primary or contralateral breast cancers.

Thus, in conclusion, while the relationship between hormonal factors and breast cancer in $B R C A 1$ carriers is complex, data from clinical studies do suggest that endocrine factors play a role in the development of breast cancer in these women. These factors are summarized in Table 1.

\section{Synthesis and perspectives}

We have reviewed evidence that: (i) BRCAl mutations confer an increased risk for several types of hormoneresponsive cancers; (ii) BRCA1 regulates ER- $\alpha$ and AR activity; (iii) hormonal factors may contribute to Brcal-dependent tumorigenesis in mice; and (iv) hormonal factors appear to modify the risk for $B R C A 1$ mutant human breast cancers. These considerations suggest a model of BRCAl mutant tumorigenesis in which loss of BRCAl's caretaker function leads to accumulation of mutations within mammary epithelial cells; and these mutant cells are stimulated to proliferate due to loss of the normal regulation of estrogen-stimulated cell proliferation. BRCA1 may also act to promote mammary epithelial cell differentiation, thus reducing the number mammary stem cells that are potential 'targets' for cancer development. This model still does not explain the high frequency of ER- $\alpha$ negativity in BRCA1-mutant mouse and human mammary cancers. Here, we postulate that the pathogenesis of these tumors follows a unique pathway in which hormonal stimulation is required early on, followed by loss of hormone receptors as a later event.
While the data we have presented are suggestive, further evidence is required to confirm the contribution of hormonal functions to the etiology of BRCA1dependent breast cancers. The development of such evidence will require a greater understanding of the molecular pathway(s) of BRCA1-dependent carcinogenesis, particularly the early events in this pathway and the timing and mechanism(s) for the loss of hormone receptor expression. The development of prospective data on the impact of hormone-associated risk factors and hormonal interventions on breast cancer risk in BRCAl mutation carriers, with a sufficient duration of follow-up, will also assist in determining the physiological relevance of the $B R C A 1$ hormone-regulatory activity. Thus far, the cancerassociated $B R C A 1$ mutations studied in the laboratory confer loss or attenuation of the ability of BRCA1 to mediate DNA repair-related functions as well as hormone-regulatory functions. Based on a greater understanding of the structural basis of the BRCA1: ER- $\alpha$ interaction, it may be possible to engineer a BRCA1 mutation that dissociates these two classes of functions. If so, well-designed animal studies (e.g., 'knock-in' of mutant Brcal genes) could further elucidate the role of hormonal factors in BRCA1dependent mammary carcinogenesis.

If this hypothesis that a defect in hormonal regulation contributes to BRCA1 is correct, it would suggest that hormonal prevention of BRCA1 mutant breast cancers, whether by oophorectomy, tamoxifen, or other agents, will be most effective if initiated at an early age. Indeed a study of prophylactic oophorectomy in $B R C A 1$ carriers suggests that this procedure is more efficacious in preventing breast cancer if performed at a younger age (Rebbeck 2000). It remains to be settled whether tamoxifen is an effective chemoprevention agent in $B R C A 1$ mutation carriers. We cited a new study showing that tamoxifen stimulates the development of mammary hyperplasias and carriers in Brcal-deficient transgenic mice (Jones et al. 2005). However, the relevance of this study to $B R C A 1$ mutant breast cancers in humans is unclear, since the mice had two mutant BRCA1 alleles, whereas human carriers retain one wild-type allele. Mice heterozygous for the Brcal exon 11 deletion have not been reported to develop cancer.

\section{Funding}

Supported in part by USPHS grant R01-CA82599 and by a grant from the Susan G Komen Breast Cancer Foundation (BCTR0201295). 


\section{References}

Adem C, Soderberg CL, Hafner K, Reynolds C, Slezak JM, Sinclair CS, Sellers TA, Schaid DJ, Couch F, Hartmann LC \& Jenkins RB 2004 ERBB2, TBX2, RPS6KB1, and $\mathrm{MYC}$ alterations in breast tissues of BRCA1 and BRCA2 mutation carriers. Genes Chromosomes and Cancer $\mathbf{4 1}$ $1-11$.

Ando S, De Amicis F, Rago V, Carpino A, Maggiolini M, Panno ML \& Lanzino M 2002 Breast cancer: from estrogen to androgen receptor. Molecular and Cellular Endocrinology 193 121-128.

Antoniou A, Pharoah PD, Narod S, Risch HA, Eyfjord JE, Hopper JL, Loman N, Olsson H, Johannsson O, Borg A, Pasini B, Radice P, Manoukian S, Eccles DM, Tang N, Olah E, Anton-Culver H, Warner E, Lubinski J, Gronwald J, Gorski B, Tulinius H, Thorlacius S, Eerola H, Nevanlinna H, Syrjakoski K, Kallioniemi OP, Thompson D, Evans C, Peto J, Lalloo F, Evans DG \& Easton DF 2003 Average risks of breast and ovarian cancer associated with BRCA1 or BRCA2 mutations detected in case series unselected for family history: a combined analysis of 22 studies. American Journal of Human Genetics 72 1117-1130.

Arbeit JM, Howley PM \& Hanahan D 2003 Chronic estrogen-induced cervical and vaginal squamous carcinogenesis in human papillomavirus type 16 transgenic mice. PNAS 93 2930-2935.

Archey WB, McEachern KA, Robson M, Offit K, Vaziri SA, Casey G, Borg A \& Arrick BA 2002 Increased CpG methylation of the estrogen receptor gene in BRCA1-linked estrogen receptor-negative breast cancers. Oncogene 21 7034-7041.

Armes JE, Trute L, White D, Southey MC, Hammet F, Tesoriero A, Hutchins AM, Dite GS, McCredie MR, Giles GG, Hopper JL \& Venter DJ 1999 Distinct molecular pathogeneses of early-onset breast cancers in BRCA1 and BRCA2 mutation carriers: a population-based study. Cancer Research 59 2011-2017.

Barkhem T, Carlsson B, Nilsson Y, Enmark E, Gustafsson J \& Nilsson S 1998 Differential response of estrogen receptor alpha and estrogen receptor beta to partial estrogen agonists/antagonists. Molecular Pharmacology 54 105-112.

Bennett LM, McAllister KA, Malphurs J, Ward T, Collins NK, Seely JC, Gowen LC, Koller BH, Davis BJ \& Wiseman RW 2000 Mice heterozygous for a Brcal or Brca2 mutation display distinct mammary gland and ovarian phenotypes in response to diethylstilbestrol. Cancer Research 60 3461-3469.

Berns EM, Dirkzwager-Kiel MJ, Kuenen-Boumeester V, Timmermans M, Verhoog LC, van den Ouweland AM, Meijer-Heijboer H, Klijn JG \& van der Kwast TH 2003 Androgen pathway dysregulation in BRCA1-mutated breast tumors. Breast Cancer Research and Treatment 79 $121-127$
Bork P, Hofmann K, Bucher P, Neuwald AF, Altschul SF \& Koonin EV 1997 A superfamily of conserved domains in DNA damage-responsive cell cycle checkpoint proteins.

Federation of American Societies for Experimental Biology Journal 11 68-76.

Bradlow HL, Michnovich J, Telang NT \& Osborne MP 1991 Effects of dietary indole-3-carbinol on estradiol metabolism and spontaneous mammary tumors in mice. Carcinogenesis 12 1571-1574.

Breast Cancer Linkage Consortium 1997 Pathology of familial breast cancer differences between breast cancers in carriers of BRCA1 or BRCA2 mutations and sporadic cases. Lancet 349 1505-1510.

Brodie SG, Xu X, Qiao W, Li WM, Cao L \& Deng CX 2001 Multiple genetic changes are associated with mammary tumorigenesis in Brcal conditional knockout mice. Oncogene 20 17514-17523.

Brzovic PS, Rajagopal P, Hoyt DW, King MC \& Klevit RE 2001 Structure of a BRCA1-BARD1 heterodimeric RING-RING complex. Nature Structural Biology 8 833-837.

Cabanes A, Wang M, Olivo S, DeAssis S, Gustafsson JA, Khan G \& Hilakivi-Clarke L 2004 Prepubertal estradiol and genistein exposures up-regulate BRCA1 mRNA and reduce mammary tumorigenesis. Carcinogenesis 25 741-748.

Carter TH, Liu K, Ralph W Jr, Chen D, Qi M, Fan S, Yuan F, Rosen EM \& Auborn KJ 2002 Diindolylmethane alters gene expression in human keratinocytes in vitro. Journal of Nutrition 132 3314-3324.

Collaborative Group on Hormonal Factors in Breast Cancer 1996 Breast cancer and hormonal contraceptives: collaborative reanalysis of individual data on 53297 women with breast cancer and 100239 women without breast cancer from 54 epidemiological studies. Collaborative Group on Hormonal Factors in Breast Cancer. Lancet 347 1713-1727.

Collaborative Group on Hormonal Factors in Breast Cancer 1997 Breast cancer and hormone replacement therapy: collaborative reanalysis of data from 51 epidemiological studies of 52705 women with breast cancer and 108411 women without breast cancer. Lancet 350 1047-1059.

Deng CX 2002 Tumor formation in Brcal conditional mutant mice. Environmental Molecular Mutagenesis 39 171-177.

de Villiers EM 2003 Relationship between steroid hormone contraceptives and HPV, cervical intraepithelial neoplasia and cervical carcinoma. International Journal of Cancer $103705-758$.

Easton DF, Ford D \& Bishop DT 1995 Breast and ovarian cancer incidence in BRCA1-mutation carriers. Breast Cancer Linkage Consortium. American Journal of Human Genetics 56 265-271.

Eisinger F, Jacquemier J, Charpin C, Stoppa-Lyonnet D, Bressac-de Paillerets B, Peyrat JP, Longy M, Guinebretiere JM, Sauvan R, Noguchi T, Birnbaum D \& Sobol H 1998 Mutations at BRCA1 the medullary 
breast carcinoma revisited. Cancer Research $\mathbf{5 8}$ 1588-1592.

Elson DA, Riley RR, Lacey A, Thordarson G, Talamantes FJ \& Arbeit JM 2000 Sensitivity of the cervical transformation zone to estrogen-induced squamous carcinogenesis. Cancer Research 60 1267-1275.

Esteller M, Silva JM, Dominguez G, Bonilla F, Matias-Guiu X, Lerma E, Bussaglia E, Prat J, Harkes IC, Repasky EA, Gabrielson E, Schutte M, Baylin SB \& Herman JG 2000 Promoter hypermethylation and BRCA1 inactivation in sporadic breast and ovarian tumors. Journal of the National Cancer Institute 92 564-569.

Fan S, Wang JA, Yuan RQ, Ma YX, Meng Q, Erdos MR, Brody LC, Goldberg ID \& Rosen EM 1998 BRCA1 as a potential human prostate tumor suppressor: modulation of proliferation, damage responses and expression of cell regulatory proteins. Oncogene $\mathbf{1 6}$ 3069-3082.

Fan S, Wang J, Yuan R, Ma Y, Meng Q, Erdos MR, Pestell RG, Yuan F, Auborn KJ, Goldberg ID \& Rosen EM 1999 BRCA1 inhibition of estrogen receptor signaling in transfected cells. Science 284 1354-1356.

Fan S, Meng Q, Gao B, Grossman J, Yadegari M, Goldberg ID \& Rosen EM 2000 Alcohol stimulates estrogen receptor signaling in human breast cancer cell lines. Cancer Research 60 5635-5639.

Fan S, Ma YX, Wang C, Yuan RQ, Meng Q, Wang JA, Erdos M, Goldberg ID, Webb P, Kushner PJ, Pestell RG \& Rosen EM 2001a Role of direct interaction in BRCA1 inhibition of estrogen receptor activity. Oncogene 20 77-87.

Fan S, Yuan R, Ma YX, Meng Q, Goldberg ID \& Rosen EM $2001 b$ Mutant BRCA1 genes antagonize phenotype of wild type BRCA1. Oncogene 20 8215-8235.

Fan S, Ma YX, Wang C, Yuan RQ, Meng Q, Wang JA, Erdos M, Goldberg ID, Webb P, Kushner PJ, Pestell RG \& Rosen EM 2002 p300 Modulates the BRCA1 inhibition of estrogen receptor activity. Cancer Research 62 141-151.

Ferro P, Catalano MG, Dell'Eva R, Fortunati N \& Pfeffer U 2002 The androgen receptor CAG repeat: a modifier of carcinogenesis? Molecular and Cellular Endocrinology 193 109-120.

Fisher B, Costantino JP, Wickerham DL, Redmond CK, Kavanah M, Cronin WM, Vogel V, Robidoux A, Dimitrov N, Atkins J, Daly M, Wieand S, Tan-Chiu E, Ford L \& Wolmark N 1998 Tamoxifen for prevention of breast cancer Report of the National Surgical Adjuvant Breast and Bowel Project P-1 Study. Journal of the National Cancer Institute 90 1371-1388.

Foulkes WD, Stefansson IM, Chappuis PO, Begin LR, Goffin JR, Wong N, Trudel M \& Akslen LA 2003 Germline BRCA1 mutations and a basal epithelial phenotype in breast cancer. Journal of the National Cancer Institute 95 1482-1485.

Gowen LC, Johnson BL, Latour AM, Sulik KK \& Koller BH 1996 Brcal deficiency results in early embryonic lethality characterized by neuroepithelial abnormalities. Nature Genetics 12 191-194.

Grabrick DM, Hartmann LM, Cerhan GR, Vierkant RA, Therneau TM, Vachon CM, Olson JE, Couch FJ, Anderson KE, Pankratz VS \& Sellers TA 2000 Risk of breast cancer with oral contraceptive use in women with a family history of breast cancer. Journal of the American Medical Association 284 1791-1798.

Grushko TA, Dignam JJ, Das S, Blackwood AM, Perou CM, Ridderstrale KK, Anderson KN, Wei MJ, Adams AJ, Hagos FG, Sveen L, Lynch HT, Weber BL \& Olopade OI 2004 MYC is amplified in BRCA1-associated breast cancers. Clinical Cancer Research 10 499-507.

Hakem R, de la Pompa JL, Sirard C, Mo R, Woo M, Hakem A, Wakeham A, Potter J, Reitmair A, Billia F, Firpo E, Hui CC, Roberts J, Rossant J \& Mak TW 1996 The tumor suppressor gene Brcal is required for embryonic cellular proliferation in the mouse. Cell 85 1009-1023.

Hakem R, de la Pompa JL, Elia A, Potter J \& Mak TW 1997 Partial rescue of Brcal (5-6) early embryonic lethality by p53 or p21 null mutation. Nature Genetics 16 298-302.

Hall JM \& McDonnell DP 1999 The estrogen receptor betaisoform (ERbeta) of the human estrogen receptor modulates ERalpha transcriptional activity and is a key regulator of the cellular response to estrogens and antiestrogens. Endocrinology 140 5566-5578.

Hartge P, Chatterjee N, Wacholder S, Brody LC, Tucker MA \& Struewing JP 2002 Breast cancer risk in Ashkenazi BRCA1/2 mutation carriers effects of reproductive history. Epidemiology 13 255-261.

Hashizume R, Fukuda M, Maeda I, Nishikawa H, Oyake D, Yabuki Y, Ogata H \& Ohta T 2001 The RING heterodimer BRCA1-BARD1 is a ubiquitin ligase inactivated by a breast cancer-derived mutation. Journal of Biological Chemistry 276 14537-14540.

Heimdal K, Skovlund E \& Moller P 2002 Oral contraceptives and risk of familial breast cancer. Cancer Detection and Prevention 26 23-27.

Henderson BE \& Feigelson HS 2000 Hormonal carcinogenesis. Carcinogenesis 21 427-433.

Holmes MD \& Willett WC 2004 Does diet affect breast cancer risk? Breast Cancer Research 6 170-178.

Jeffy BD, Chirnomas RB, Chen EJ, Gudas JM \& Romagnolo DF 2002 Activation of the aromatic hydrocarbon receptor pathway is not sufficient for transcriptional repression of BRCA-1: requirements for metabolism of benzo[a]pyrene to $7 \mathrm{r}, 8 \mathrm{t}$-dihydroxy-9t,10-epoxy-7,8,9,10-tetrahydrobenzo[a]pyrene. Cancer Research 62 113-121.

Jernstrom H, Lerman C, Ghadirian P, Lynch HT, Weber B, Garber J, Daly M, Olopade OI, Foulkes WD, Warner E, Brunet JS \& Narod SA 1999 Pregnancy and risk of early breast cancer in carriers of BRCA1 and BRCA2. Lancet 354 1846-1850.

Jernstrom H, Lubinski J, Lynch HT, Ghadirian P, Neuhausen S, Isaacs C, Weber BL, Horsman D, Rosen B, Foulkes WD, Friedman E, Gershoni-Baruch R, Ainsworth P, Daly M, Garber J, Olsson H, Sun P \& 
Narod SA 2004 Breast-feeding and the risk of breast cancer in BRCA1 and BRCA2 mutation carriers. Journal of the National Cancer Institute 96 1094-1098.

Jisa E \& Jungbauer A 2003 Kinetic analysis of estrogen receptor homo- and heterodimerization in vitro. Journal of Steroid Biochemistry and Molecular Biology $\mathbf{8 4}$ 141-148.

Johannsson OT, Idvall I, Anderson C, Borg A, Barkardottir RB, Egilsson V \& Olsson H 1997 Tumour biological features of BRCA1-induced breast and ovarian cancer. European Journal of Cancer 33 362-371.

Jones LP, Li M, Halama ED, Ma Y, Lubet R, Grubbs CJ, Deng C-X, Rosen EM \& Furth PA 2005 Promotion of mammary cancer development by tamoxifen in a mouse model of Brca1-mutation related breast cancer. Oncogene, 24 3554-3562.

Kauff ND, Satagopan JM, Robson ME, Scheuer L, Hensley M, Hudis CA, Ellis NA, Boyd J, Borgen PI, Barakat RR, Norton L, Castiel M, Nafa K \& Offit K 2002 Riskreducing salpingo-oophorectomy in women with a BRCA1 or BRCA2 mutation. New England Journal of Medicine 346 1609-1615.

Kauraniemi P, Hedenfalk I, Persson K, Duggan DJ, Tanner M, Johannsson O, Olsson H, Trent JM, Isola J \& Borg A 2000 MYB oncogene amplification in hereditary BRCA1 breast cancer. Cancer Research 60 5323-5328.

Kawai H, Li H, Chun P, Avraham S \& Avraham HK 2002 Direct interaction between BRCA1 and the estrogen receptor regulates vascular endothelial growth factor (VEGF) transcription and secretion in breast cancer cells. Oncogene 21 7730-7739.

Kelly MJ \& Levin ER 2001 Rapid actions of plasma membrane estrogen receptors. Trends in Endocrinology and Metabolism 12 152-156.

King MC, Wieand S, Hale K, Lee M, Walsh T, Owens K, Tait J, Ford L, Dunn BK, Costantino J, Wickerham L, Wolmark N, Fisher B; National Surgical Adjuvant Breast and Bowel Project 2001 Tamoxifen and breast cancer incidence among women with inherited mutations in BRCA1 and BRCA2 National Surgical Adjuvant Breast and Bowel Project (NSABP-P1) Breast Cancer Prevention Trial. Journal of the American Medical Association 286 2251-2256.

King TA, Gemignani ML, Li W, Giri DD, Panageas KS, Bogomolniy F, Arroyo C, Olvera N, Robson ME, Offit K, Borgen PI \& Boyd J 2004 Increased progesterone receptor expression in benign epithelium of BRCA1related breast cancers. Cancer Research 64 5051-5053.

Kubista M, Rosner M, Kubista E, Bernaschek G \& Hengstschlager M 2002 Brcal regulates in vitro differentiation of mammary epithelial cells. Oncogene 21 4747-4756.

Kuiper GG, Lemmen JG, Carlsson B, Corton JC, Safe SH, van der Saag PT, van der Burg B \& Gustafsson JA 1998 Interaction of estrogenic chemicals and phytoestrogens with estrogen receptor beta. Endocrinology 1394252 6263 .
Lakhani SR, Jacquemier J, Sloane JP, Gusterson BA, Anderson TJ, van de Vijver MJ, Farid LM, Venter D, Antoniou A, Storfer-Isser A, Smyth E, Steel CM, Haites N, Scott RJ, Goldgar D, Neuhausen S, Daly PA, Ormiston W, McManus R, Scherneck S, Ponder BA, Ford D, Peto J, Stoppa-Lyonnet D, Easton DF et al. 1998 Multifactorial analysis of differences between sporadic breast cancers and cancers involving BRCA1 and BRCA2 mutations. Journal of the National Cancer Institute 90 1138-1145.

Lakhani SR, Van De Vijver MJ, Jacquemier J, Anderson TJ, Osin PP, McGuffog L \& Easton DF 2002 The pathology of familial breast cancer predictive value of immunohistochemical markers estrogen receptor, progesterone receptor, HER-2, and p53 in patients with mutations in BRCA1 and BRCA2. Journal of Clinical Oncology 20 2310-2318.

Lane TF, Deng C, Elson A, Lyu MS, Kozak CA \& Leder P 1995 Expression of Brcal is associated with terminal differentiation of ectodermally and mesodermally derived tissues in mice. Genes and Development 9 2712-2722.

Li S, Hursting SD, Davis BJ, McLachlan JA \& Barrett JC 2003 Environmental exposure, DNA methylation, and gene regulation: lessons from diethylstilbesterol-induced cancers. Annals of the New York Academy of Science $\mathbf{9 8 3}$ 161-169.

Liede A, Karlan BY \& Narod SA 2004 Cancer risks for male carriers of germline mutations in BRCA1 or BRCA2: a review of the literature. Journal of Clinical Oncology 22 735-742.

Liu CY, Flesken-Nikitin A, Li S, Zeng Y \& Lee WH 1996 Inactivation of the mouse Brcal gene leads to failure in the morphogenesis of the egg cylinder in early postimplantation development. Genes and Development 10 1835-1843.

Lubinski J, Phelan CM, Ghadirian P, Lynch HT, Garber J, Weber B, Tung N, Horsman D, Isaacs C, Monteiro AN, Sun P \& Narod SA 2004 Cancer variation associated with the position of the mutation in the BRCA2 gene. Familial Cancer 3 1-10.

Ma YX, Tomita Y, Fan S, Wu K, Tong Y, Zhao Z, Song LN, Goldberg ID \& Rosen EM 2005 Structural determinants of the BRCA1: estrogen receptor interaction. Oncogene 24 1831-1846.

McGuire V, Felberg A, Mills M, Ostrow KL, DiCioccio R, John EM, West DW \& Whittemore AS 2004 Relation of contraceptive and reproductive history to ovarian cancer risk in carriers and noncarriers of BRCA1 gene mutations. American Journal of Epidemiology $\mathbf{1 6 0}$ 613-618.

Marcus JN, Watson P, Page DL, Narod SA, Lenoir GM, Tonin P, Linder-Stephenson L, Salerno G, Conway TA \& Lynch HT 1996 Hereditary breast cancer pathobiology, prognosis, and BRCA1 and BRCA2 gene linkage. Cancer 77 697-709.

Marks JR, Huper G, Vaughn JP, Davis PL, Norris J, McDonnell DP, Wiseman RW, Futreal PA \& Iglehart JD 
1997 BRCA1 is not directly responsive to estrogen.

Oncogene 14 115-121.

Marquis ST, Rajan JV, Wynshaw-Boris A, Xu J, Yin GY, Abel KJ, Weber BL \& Chodosh LA 1995 The developmental pattern of Brcal expression implies a role in differentiation of the breast and other tissues. Nature Genetics 11 17-26.

Meng Q, Yuan F, Goldberg ID, Rosen EM, Auborn K \& Fan S 2000a Indole-3-carbinol is a negative regulator of estrogen receptor-alpha signaling in human tumor cells. Journal of Nutrition 130 2927-2931.

Meng Q, Qi M, Chen DZ, Yuan R, Goldberg ID, Rosen EM, Auborn K \& Fan S 2000b Suppression of breast cancer invasion and migration by indole-3-carbinol: associated with up-regulation of BRCA1 and E-cadherin/catenin complexes. Journal of Molecular Medicine 78 155-165.

Merajver SD, Frank TS, Xu J, Pham TM, Calzone KA, Bennett-Baker P, Chamberlain J, Boyd J, Garber JE, Collins FS et al. 1995 Germline BRCA1 mutations and loss of the wild-type allele in tumors from families with early onset breast and ovarian cancer. Clinical Cancer Research 1 539-544.

Metcalfe K, Lynch HT, Ghadirian P, Tung N, Olivotto I, Warner E, Olopade OI, Eisen A, Weber B, McLennan J, Sun P, Foulkes WD \& Narod SA 2004 Contralateral breast cancer in BRCA1 and BRCA2 mutation carriers. Journal of Clinical Oncology 22 2328-2335.

Miki Y, Swensen J, Shattuck-Eidens D, Futreal PA, Harshman K, Tavtigian S, Liu Q, Cochran C, Bennett LM, Ding W et al. 1994 A strong candidate for the breast and ovarian cancer susceptibility gene BRCA1. Science 266 66-71.

Monteiro AN, August A \& Hanafusa H 1996 Evidence for a transcription activation function of BRCA1 C-terminal region. PNAS 93 13595-13599.

Mosselman S, Polman J \& Dijkema R 1996 ER-beta: identification and characterization of a novel human estrogen receptor. Federation of European Biochemical Societies Letters 392 49-53.

Narod SA 2001 Hormonal prevention of hereditary breast cancer. Annals of the New York Academy of Sciences 952 36-43. Review.

Narod SA, Brunet JS, Ghadirian P, Robson M, Heimdal K, Neuhausen SL, Stoppa-Lyonnet D, Lerman C, Pasini B, de los Rios P, Weber B, Lynch H; Hereditary Breast Cancer Clinical Study Group 2000 Tamoxifen and risk of contralateral breast cancer in BRCA1 and BRCA2 mutation carriers a case-control study. Lancet 356 1876-1881.

Narod SA, Dube MP, Klijn J, Lubinski J, Lynch HT, Ghadirian P, Provencher D, Heimdal K, Moller P, Robson M, Offit K, Isaacs C, Weber B, Friedman E, Gershoni-Baruch R, Rennert G, Pasini B, Wagner T, Daly M, Garber JE, Neuhausen SL, Ainsworth P, Olsson H, Evans G, Osborne M, Couch F, Foulkes WD, Warner E, Kim-Sing C, Olopade O, Tung N, Saal HM, Weitzel J, Merajver S, Gauthier-Villars M, Jernstrom H, Sun P \&
Brunet JS 2002 Oral contraceptives and the risk of breast cancer in BRCA1 and BRCA2 mutation carriers. Journal of the National Cancer Institute 94 1773-1779.

Osin P, Gusterson BA, Philp E, Waller J, Bartek J, Peto J \& Crook T 1998 Predicted anti-oestrogen resistance in BRCA-associated familial breast cancers. European Journal of Cancer 34 1683-1686.

Ozcelik H, To MD, Couture J, Bull SB \& Andrulis IL 1998 Preferential allelic expression can lead to reduced expression of BRCA1 in sporadic breast cancers. International Journal of Cancer 77 1-6.

Palacios J, Honrado E, Osorio A, Cazorla A, Sarrio D, Barroso A, Rodriguez S, Cigudosa JC, Diez O, Alonso C, Lerma E, Sanchez L, Rivas C \& Benitez J 2004 Immunohistochemical characteristics defined by tissue microarray of hereditary breast cancer not attributable to BRCA1 or BRCA2 mutations: differences from breast carcinomas arising in BRCA1 and BRCA2 mutation carriers. Clinical Cancer Research 9 3606-3614.

Park JJ, Irvine RA, Buchanan G, Koh SS, Park JM, Tilley WD, Stallcup MR, Press MF \& Coetzee GA 2000 Breast cancer susceptibility gene 1 (BRCA1) is a coactivator of the androgen receptor. Cancer Research 60 5946-5949.

Pettersson K, Delaunay F \& Gustafsson JA 2000 Estrogen receptor beta acts as a dominant regulator of estrogen signaling. Oncogene 19 4970-4978.

Phillips KW, Goldsworthy SM, Bennett LM, Brownlee HA, Wiseman RW \& Davis BJ 1997 Brcal is expressed independently of hormonal stimulation in the mouse ovary. Laboratory Investigation 76 419-425.

Phillips KA, Andrulis IL \& Goodwin PJ 1999 Breast carcinomas arising in carriers of mutations in BRCA1 or BRCA2 are they prognostically different? Journal of Clinical Oncology 17 3653-3663.

Pike AC, Brzozowski AM, Hubbard RE, Bonn T, Thorsell AG, Engstrom O, Ljunggren J, Gustafsson JA \& Carlquist M 1999 Structure of the ligand-binding domain of oestrogen receptor beta in the presence of a partial agonist and a full antagonist. European Molecular Biology Organization Journal 18 4608-4618.

Quenneville LA, Phillips KA, Ozcelik H, Parkes RK, Knight JA, Goodwin PJ, Andrulis IL \& O'Malley FP 2002 HER$2 /$ neu status and tumor morphology of invasive breast carcinomas in Ashkenazi women with known BRCA1 mutation status in the Ontario Familial Breast Cancer Registry. Cancer 95 2068-2075.

Rajan JV, Wang M, Marquis ST \& Chodosh LA 1996 Brca2 is coordinately regulated with Brcal during proliferation and differentiation in mammalian epithelial cells. PNAS 93 3078-3083.

Rajan JV, Marquis ST, Gardner HP \& Chodosh LD 1997 Developmental expression of Brca 2 colocalizes with Brca 1 and is associated with proliferation and differentiation in multiple tissues. Developmental Biology 184 385-401.

Rattenborg T, Gjermandsen I \& Bonefeld-Jorgensen EC 2002 Inhibition of E2-induced expression of BRCA1 by persistent organochlorines. Breast Cancer Research 4 R12. 
Razandi M, Pedram A, Rosen EM \& Levin ER 2004 BRCA1 inhibits membrane estrogen and growth factor receptor signaling to cell proliferation in breast cancer. Molecular and Cellular Biology 24 5900-5913.

Rebbeck TR 2000 Prophylactic oophorectomy in BRCA1 and BRCA2 mutation carriers. Journal of Clinical Oncology 200018 (Suppl 21) 100-103.

Rebbeck TR, Wang Y, Kantoff PW, Krithivas K, Neuhausen SL, Godwin AK, Daly MB, Narod SA, Brunet JS, Vesprini D, Garber JE, Lynch HT, Weber BL \& Brown M 2001 Modification of BRCA1- and BRCA2-associated breast cancer risk by AIB1 genotype and reproductive history. Cancer Research 61 5420-5424.

Rebbeck TR, Lynch HT, Neuhausen SL, Narod SA, Van't Veer L, Garber JE, Evans G, Isaacs C, Daly MB, Matloff E, Olopade OI, Weber BL; Prevention and Observation of Surgical End Points Study Group 2002 Prophylactic oophorectomy in carriers of BRCA1 or BRCA2 mutations. New England Journal of Medicine 346 $1616-1622$.

Rice JC, Massey-Brown KS \& Futscher BW 1998 Aberrant methylation of the BRCA1 CpG island promoter is associated with decreased BRCA1 mRNA in sporadic breast cancer cells. Oncogene 17 1807-1812.

Rio PG, Maurizis JC, Peffault de Latour M, Bignon YJ \& Bernard-Gallon DJ 1999 Quantification of BRCA1 protein in sporadic breast carcinoma with or without loss of heterozygosity of the BRCA1 gene. International Journal of Cancer $\mathbf{8 0} 823-826$.

Robson ME, Chappuis PO, Satagopan J, Wong N, Boyd J, Goffin JR, Hudis C, Roberge D, Norton L, Begin LR, Offit K \& Foulkes WD 2004 A combined analysis of outcome following breast cancer differences in survival based on BRCA1/BRCA2 mutation status and administration of adjuvant treatment. Breast Cancer Research 6 R8-R17.

Rodriguez JA \& Henderson BR 2000 Identification of a functional nuclear export sequence in BRCA1. Journal of Biological Chemistry 275 38589-38596.

Rosen EM, Fan S, Pestell RG \& Goldberg ID 2003 BRCA1 gene in breast cancer. Journal of Cellular Physiology 196 $19-41$.

Ruffner H, Joazeiro CA, Hemmati D, Hunter T \& Verma IM 2001 Cancer-predisposing mutations within the RING domain of BRCA1: loss of ubiquitin protein ligase activity and protection from radiation hypersensitivity. PNAS 98 5134-5139.

Schairer C, Lubin J, Troisi R, Sturgeon S, Brinton L \& Hoover R 2000 Menopausal estrogen and estrogenprogestin replacement therapy and breast cancer risk. Journal of the American Medical Association 283 485-491.

Shertzer HG \& Senft AP 2000 The micronutrient indole-3carbinol: implications for disease and chemoprevention. Drug Metabolism and Drug Interactions 17 159-188.

Sorlie T, Tibshirani R, Parker J, Hastie T, Marron JS, Nobel A, Deng S, Johnsen H, Pesich R, Geisler S, Demeter J,
Perou CM, Lonning PE, Brown PO, Borresen-Dale AL \& Botstein D 2003 Repeated observation of breast tumor subtypes in independent gene expression data sets. PNAS 100 8418-8423.

Staff S, Isola J \& Tanner M 2003 Haplo-insufficiency of BRCA1 in sporadic breast cancer. Cancer Research 63 4978-4983.

Streuwing J, Hartge P, Wacholder S, Baker SM, Berlin M, McAdams M, Timmerman MM, Brody LC \& Tucker MA 1997 The risk of cancer associated with specific mutations of BRCA1 and BRCA2 among Ashkenazi Jews. New England Journal of Medicine 336 1401-1408.

Tavtigian SV, Simard J, Rommens J, Couch F, ShattuckEidens D, Neuhausen S, Merajver S, Thorlacius S, Offit K, Stoppa-Lyonnet D, Belanger C, Bell R, Berry S, Bogden R, Chen Q, Davis T, Dumont M, Frye C, Hattier T, Jammulapati S, Janecki T, Jiang P, Kehrer R, Leblanc JF, Goldgar DE et al. 1996 The complete BRCA2 gene and mutations in chromosome 13q-linked kindreds. Nature Genetics 12 333-337.

Taylor J, Lymboura M, Pace PE, A'hern RP, Desai AJ, Shousha S, Coombes RC \& Ali S 1998 An important role for BRCA1 in breast cancer progression is indicated by its loss in a large proportion of nonfamilial breast cancers. International Journal of Cancer 79 334-342.

Thakur S, Zhang HB, Peng Y, Le H, Carroll B, Ward T, Yao J, Farid LM, Couch FJ, Wilson RB \& Weber BL 1997 Localization of BRCA1 and a splice variant identifies the nuclear localization signal. Molecular and Cellular Biology 17 444-452.

The Women's Health Initiative Steering Committee 2004 Effects of conjugated equine estrogen in postmenopausal women with hysterectomy. Journal of the American Medical Association 291 1701-1712.

Thomas JE, Smith M, Tonkinson JL, Rubinfeld B \& Polakis P 1997 Induction of phosphorylation of BRCA1 during the cell cycle and after DNA damage. Cell Growth and Differentiation 8 801-809.

Thompson D, Easton DF \& Breast Cancer Linkage Consortium 2002 Cancer Incidence in BRCA1 mutation carriers. Journal of the National Cancer Institute 94 $1358-1365$.

Tirkkonen M, Johannsson O, Agnarsson BA, Olsson H, Ingvarsson S, Karhu R, Tanner M, Isola J, Barkardottir RB, Borg A \& Kallioniemi OP 1997 Distinct somatic genetic changes associated with tumor progression in carriers of BRCA1 and BRCA2 germ-line mutations. Cancer Research 57 1222-1227.

Ursin G, Henderson BE, Haile RW, Pike MC, Zhou N, Diep A \& Bernstein L 1997 Does oral contraceptive use increase the risk of breast cancer in women with BRCA1/ BRCA2 mutations more than in other women? Cancer Research 57 3678-3681.

Vaziri SA, Tubbs RR, Darlington G \& Casey G 2001 Absence of CCND1 gene amplification in breast tumours 
of BRCA1 mutation carriers. Molecular Pathology 54 259-263.

Venkitaraman AR 2002 Cancer susceptibility and the functions of BRCA1 and BRCA2. Cell 108 171-182.

Verhoog LC, Brekelmans CT, Seynaeve C, van den Bosch LM, Dahmen G, van Geel AN, Tilanus-Linthorst MM, Bartels CC, Wagner A, van den Ouweland A, Devilee P, Meijers-Heijboer EJ \& Klijn JG 1998 Survival and tumour characteristics of breast-cancer patients with germline mutations of BRCA1. Lancet 351 316-321.

Warner E, Foulkes W, Goodwin P, Meschino W, Blondal J, Paterson C, Ozcelik H, Goss P, Allingham-Hawkins D, Hamel N, Di Prospero L, Contiga V, Serruya C, Klein M, Moslehi R, Honeyford J, Liede A, Glendon G, Brunet JS \& Narod S 1999 Prevalence and penetrance of BRCA1 and BRCA2 gene mutations in unselected Ashkenazi Jewish women with breast cancer. Journal of the National Cancer Institute 91 1241-1247.

Weaver Z, Montagna C, Xu X, Howard T, Gadina M, Brodie SG, Deng CX \& Ried T 2002 Mammary tumors in mice conditionally mutant for Brcal exhibit gross genomic instability and centrosome amplification yet display a recurring distribution of genomic imbalances that is similar to human breast cancer. Oncogene 21 50975107.

Weihua Z, Saji S, Makinen S, Cheng G, Jensen EV, Warner M \& Gustafsson JA 2000 Estrogen receptor (ER) beta, a modulator of ER alpha in the uterus. PNAS 97 59365941.

Whittemore AS, Balise RR, Pharoah PD, Dicioccio RA, Oakley-Girvan I, Ramus SJ, Daly M, Usinowicz MB, Garlinghouse-Jones K, Ponder BA, Buys S, Senie R, Andrulis I, John E, Hopper JL \& Piver MS 2004 Oral contraceptive use and ovarian cancer risk among carriers of BRCA1 or BRCA2 mutations. British Journal of Cancer 91 1911-1915.

Wilson CA, Ramos L, Villasenor MR, Anders KH, Press MF, Clarke K, Karlan B, Chen JJ, Scully R, Livingston
D, Zuch RH, Kanter MH, Cohen S, Calzone FJ \& Slamon DJ 1999 Localization of human BRCA1 and its loss in high-grade, non-inherited breast carcinomas. Nature Genetics 21 236-240.

Wooster R, Bignell G, Lancaster J, Swift S, Seal S, Mangion J, Collins N, Gregory S, Gumbs C \& Micklem G 1995 Identification of the breast cancer susceptibility gene BRCA2. Nature 378 789-792.

Writing Group for the Women's Health Initiative Investigators 2002 Risks and benefits of estrogen plus progestin in healthy postmenopausal women: principal results from the Women's Health Initiative Randomized Controlled Trial. Journal of the American Medical Association 288 321-333.

Wu LC, Wang ZW, Tsan JT, Spillman MA, Phung A, Xu XL, Yang MC, Hwang LY, Bowcock AM \& Baer R 1996 Identification of a RING protein that can interact in vivo with the BRCA1 gene product. Nature Genetics 14 430440.

Xu X, Weaver Z, Linke SP, Li C, Gotay J, Wang XW, Harris CC, Ried T \& Deng CX $1999 a$ Centrosome amplification and a defective G2-M cell cycle checkpoint induce genetic instability in BRCA1 exon 11 isoform-deficient cells. Molecular Cell 3 389-395.

Xu X, Wagner K-U, Larson D, Weaver Z, Li C, Ried T, Hennighausen L, Wynshaw-Boris A \& Deng C-X 1999 b Conditional mutation of Brcal in mammary epithelial cells results in blunted ductal morphogenesis and tumour formation. Nature Genetics 22 37-43.

Yeh S, Hu YC, Rahman M, Lin HK, Hsu CL, Ting HJ, Kang HY \& Chang C 2000 Increase of androgeninduced cell death and androgen receptor transactivation by BRCA1 in prostate cancer cells. PNAS 97 11256-11261.

Zheng L, Annab LA, Afshari CA, Lee WH \& Boyer TG 2001 BRCA1 mediates ligand-independent transcriptional repression of the estrogen receptor. PNAS 98 9587-9592. 